\title{
English Proficiency Gain and Mediating Factors in Training: A Self-Evaluation of Vietnamese Pre-Service EFL Teachers
}

\author{
Nguyen Van Loi ${ }^{1}$ and Chung Thi Thanh Hang ${ }^{2}$ \\ Can Tho University, School of Foreign Languages, Can Tho, Vietnam \\ https://orcid.org/0000-0002-1815-1371 \\ https://orcid.org/0000-0002-6904-7179
}

\begin{abstract}
Following international language proficiency standards, Vietnam has recently set the advanced English proficiency (C1-CEFR) for teacher graduates from an English teacher education program. Considering regional differences, this standard setting has raised a concern about its feasibility. This paper aims to report the language proficiency development of English teacher trainees at a Vietnamese university as an illustration and examine training factors that may influence this proficiency outcome. To this end, a self-report questionnaire was designed to collect the data on the trainees' selfassessment of EP and their responses to the training factors. A group interview was then conducted to obtain qualitative evidence that backed up the questionnaire results. The participants were 41 fourth-year EFL teacher students, seven of whom agreed to participate in the group interview. The results showed that approximately $62.4 \%$ of the candidates self-assessed their level equivalent to the $\mathrm{C} 1$-advanced proficiency, while a significant percentage still desired additional language proficiency support. Their responses to the training factors revealed that they were overall satisfied with the effectiveness of English proficiency training. Noticeably, their proficiency scores positively correlated with their use of self-regulated learning strategies, which in turn correlated with the types of teaching and assessment activities during the training years. Their starting proficiency level also had a significant correlation to their proficiency gain at the end. These findings offer useful implications for preparing foreign language teachers in the context towards the general proficiency standards, and for understanding expectations versus realities regarding this issue.
\end{abstract}

Keywords: training factors; effectiveness; advanced proficiency; language proficiency

\footnotetext{
${ }^{1}$ Corresponding author: Nguyen Van Loi; Email: loinguyen@ctu.edu.vn

${ }^{2}$ Author: Chung Thi Thanh Hang; Email: ctthang@ctu.edu.vn
} 


\section{Introduction}

The quality of initial teacher education is central to the improvement of teaching and learning and school accountability (Gunashekar, 2016). Second language teacher education programs, therefore, need to provide sufficient knowledge base for teacher candidates. In spite of the different views on the contents of teacher professional knowledge in the field, content knowledge including LP is accepted as a teacher competence (Freeman et al., 2015; Kissau \& Algozzine, 2017) especially in foreign language teacher education (FLTE) (Glisan, Swender \& Surface, 2013; Kissau \& Algozzine, 2017; Richards, 2017; Stedick, 2013). For nonnative English teachers (NNETs) in many parts of the world, English proficiency (EP) is strongly desirable and helps build their professional confidence (Choi \& Lee, 2016), but it seems to be inadequately trained in teacher education programs (Eslami \& Fatahi, 2008; Sandhu, 2016).

The construct of general language proficiency (GLP) was early defined as the ability to communicate effectively in a target language (Canale \& Swain, 1980), or the mastery of a language (Stern, 1983). Academics in teacher education have recently argued the kind of proficiency involving "metalinguistic terminology and discourse competence for managing the classroom" (Pearson, Fonseca-Greber \& Foell, 2006, p. 508) the teacher needs in order to instruct and interact with students in ways that generate comprehensible input and a conducive environment for language learning (Freeman et al., 2015; Le \& Renandya, 2017; Richards, 2015). It is also argued that this specific LP and GLP complement each other in helping the teacher to teach effectively (Pham, 2017). In spite of the controversies on the construct (Tsang, 2017), LP standards have already been set for training, assessing and accrediting language teachers worldwide (ACTFL, 2012; Byram \& Parmenter, 2013; NESA, 2017; Pearson et al., 2006; TESOL, 2010). These LP standards, though different in contents, contexts and uses, seem to suggest that a native-like LP is needed for language teachers to function well in the classroom.

Abundant research has focused on the GLP against the benchmarks, and concluded that a high level of LP increases teachers' self-efficacy in teaching, especially managing the classroom and communicating contents (Chacón, 2005; Choi \& Lee, 2016; Tsang, 2017; Yusuf \& Novita, 2020). In contrast, teachers' LP inadequacy reduces their self-efficacy in providing comprehensible input, modelling, giving feedback and managing activities (Butler, 2004; Chen \& Goh, 2011; Copland, Garton \& Burns, 2014; Ghasemboland \& Hashim, 2013; Richards et al., 2013; Yilmaz, 2011). Although a threshold level for effective teaching is unclear (Tsang, 2017), Tsui (2003) indicated that the advanced proficiency enabled teachers to provide more accurate meaningful explanations and respond to learners' errors better than the lower level. In this respect, however, using the ACTFL standards' Oral Proficiency Interview to gauge the speaking proficiency of 2,881 teacher candidates of 11 different languages in the USA, Glisan et al. (2013) found that only $54.8 \%$ met the low advanced speaking proficiency in their target languages (e.g., German, Spanish). Noticeably, their proficiency variance emerged from their undergraduate experiences. This finding implies that teachers' LP could originate in their higher education experience, which is 
arguably the case of Vietnam, where over $90 \%$ of Vietnamese high school teachers needed upgrading their level (T. Nguyen \& Mai, 2015).

In Vietnam, English teacher education strictly follows the stipulations of the Ministry of Education and Training (MOET) with respect to training quota, recruitment procedures and program design. Given an annual quota, universities select candidates by using the results of three subject tests administered in the national school graduation examination. English is compulsory and focuses on grammar, vocabulary and reading. Since 2008, the national 2020 Project missioned by the MOET, aiming to improve foreign language instruction (Prime Minister, 2008) adopted the Common European Framework of Reference for Languages (CEFR) (Council of Europe, 2001) as standards. The CEFR contains six levels: A1, $\mathrm{A} 2$, B1, B2, C1 and C2. Following the benchmark for language teacher graduates in Europe (Cárdenas \& Chaves, 2013), C1 level, 'Proficient' or 'effective operational proficiency,' is set as a LP standard for high school teachers and graduates from FLTEPs (MOET, 2014). While the question of which LP and which level exactly is needed for a teacher's effective teaching remains unclear and controversial (Pham, 2017; Tsang, 2017), this standard setting is commonly assumed to improve foreign language instruction (Kissau, \& Algozzine, 2017). How effectively current FLTEPs prepared their trainees to meet the standard, however, remains a question (Pearson et al., 2006) and a gap in Vietnam. Little is known about the extent to which ETEPs prepare pre-service teachers to meet the advanced level, especially in the disadvantaged area like the Mekong Delta (V. Nguyen, 2015).

To fill the gap, we examined the ETEP of a representative university in the region, focusing on the following research questions:

1. What are pre-service teachers' levels of English proficiency (EP) before and upon training completion based on their self-assessment? To what extent do they attain the advanced level?

2. What are their evaluations of the EP training effectiveness and related quality factors?

\section{Literature review}

Language program evaluation is essential to inform and improve the training quality (Aldoobie, 2015). Given that this task involves a systematic process of collecting, dissecting, and interpreting information for "forming judgments about the value of a particular program" (Robinson, 2003, p.199, as cited in Peacock, 2009), which is beyond our ability to manage, we find it imperative to gain insight into which training attributes may benefit LP development.

The literature on ETEP evaluation has concentrated on some important elements for effective training. These include a needs-based curriculum, an awareness of program goals, course structuring and linkage, the balance between teachercentered and learner-centered activities, and that between content knowledge and pedagogical knowledge (Bolitho, 2016; Peacock, 2009; Sung, 2009). Regarding LP development, a sufficient emphasis is widely suggested (Bolitho, 2016; Chacón, 2005). In particular, to achieve the advanced level, Cambridge English Assessment suggests that learners need 700-800 guided learning hours (Cambridge University Press, 2013). Besides, instructional activities should place a focus on learners and 
practice, instead of theory-laden lectures (Sung, 2009); learners' awareness of the proficiency goal, their effort and time investment and willingness to practice the language outside class are also crucial elements (Chambless, 2012). Additionally, teacher educators' LP, opportunities for learner-learner interaction, and learning strategy instruction are quality attributes (Sung, 2009). Research has further confirmed that the use of self-regulated learning strategies influences LP development (Fukuda, 2017). Importantly, the onset LP level could be a crucial mediator in the advanced LP achievement (L. Nguyen, 2014).

Research on FLTE has to date largely focused on teacher preparedness for pedagogical competence or professional knowledge (Akcan, 2016; Baecher, 2012; Carmel \& Badash, 2018; Faez \& Valeo, 2012; Kiely \& Askham, 2012; Senom, Zakaria \& Shah, 2013; Uzun, 2016). A few studies have yet contributed some insights into the preparation of teachers' LP via pre-service teacher training. Peacock's (2009) study is one of the few in Hong Kong that indicated that the NNET trainees desired an increased time for EP apart from the need for further teaching practice and classroom management skills. Examining the impact of a one-year EFL teacher training program in Cambodia, Sovann and Chomdokmai (2012) assessed eighty-nine trainees using an EP test and a teaching knowledge test whose results showed that they only achieved an average level in both English and teaching knowledge. Four training elements to be improved were the learning environment, resources, curriculum and program management. This study, however, is limited in terms of the EP test which lasted only 50 minutes, a far limited time to gauge the overall EP. In Norwegian contexts, Vold (2017) noted the LP component was not prioritized in FLTEPs, and his study confirmed evidence on the LP deficiency among novice teachers and their desire for a stronger focus on oral skills. With a qualitative approach to delving into an EFL teacher preparation curriculum in Indonesia, Hadi (2019) similarly concludes that the teachers are not adequately prepared for EP, because of the lack of theorypractice balance, and a facilitative learning environment. Faez, Karas and Uchihara (2019) found that after one-year training in an MA TESOL program in Australia, most of the Chinese EFL teachers improved their EP by one level, but only $26 \%$ achieved C1. The English-medium courses, and exposure to the language environment were reported as factors contributing to their EP development. Overall, previous research has revealed a common picture that pre-service teachers are not adequately prepared for LP, but the extent to which the teachers achieve the advanced level is not mentioned in most studies.

\section{Methods}

Formative evaluation could not be undertaken, so the study focused only on the trainees' self-evaluation. We relied on a mixed-method approach (Lynch, 1996) combining a questionnaire and a group interview to collect data.

\subsection{Data collection methods}

The questionnaire consisted of two parts: Part 1 collected the participants' background information; Part 2 elicited the trainees' self-assessment of EP, and their responses to training effectiveness and related factors which were previously reviewed in the literature (see appendix 1 ). 
We adopted the CEFR self-assessment grid because of financial constraints in conducting standardized tests. Researchers further question the exact measurement of GLP due to the controversy on the construct (Tsang, 2017). Besides, combined measures such as self-rating and tests are suggested (Stern, 1983; Tsang, 2017). This is based on research findings about the relatively strong correlation between self-assessment and tests (Diamond et al., 2014; Ross, 1998; Wilson, 1999). Ma and Winke (2019) conclude that can-do statements are useful for low-stakes self-assessments. In this sense, the CEFR with both holistic descriptions and specific can-do statements and separate scales for listening, reading, spoken interaction, spoken production and writing, can facilitate learners' self-assessment, and was adopted in recent studies (e.g., Faez et al., 2019).

Five six-point scales (1 to 6 ) of each skill ranging from A1 to C2 were used for selfrating the start level and exit level. The alpha coefficients of these scales were calculated, and the overall result was $a=.886$, which means sufficient internal reliability. The participants were also asked to report proficiency proofs, which were then used to corroborate with their self-assessment.

For the self-evaluation of EP training effectiveness, five-point Likert's scales were used. The current study report the data on the following factors as indicated in Table 1.

Table 1: Factors for self-evaluation and scales

\begin{tabular}{|l|l|l|}
\hline Factors & Scales & $\begin{array}{l}\text { Alpha } \\
\text { Coefficients }\end{array}$ \\
\hline $\begin{array}{l}\text { Overall effectiveness of } \\
\text { EP training (6 items) }\end{array}$ & $\begin{array}{l}\text { 1= strongly disagree, 2= disagree, 3= } \\
\text { neutral, 4= agree, 5= strongly agree }\end{array}$ & $\alpha=.852$ \\
\hline $\begin{array}{l}\text { Teaching activities } \\
(29 \text { items })\end{array}$ & $\begin{array}{l}\text { 1= never, 2= seldom, 3= sometimes, } \\
4=\text { most of the time, 5= always }\end{array}$ & $\alpha=.921$ \\
\hline $\begin{array}{l}\text { Assessment activities } \\
(13 \text { items) }\end{array}$ & $\begin{array}{l}1=\text { never, 2= seldom, 3= sometimes, } \\
4=\text { most of the time, 5= always }\end{array}$ & $\alpha=.767$ \\
\hline $\begin{array}{l}\text { Self-regulated learning } \\
\text { strategies (5 items) }\end{array}$ & $\begin{array}{l}1=\text { never, 2= seldom, 3= sometimes, } \\
4=\text { most of the time, 5= always }\end{array}$ & $\alpha=.858$ \\
\hline
\end{tabular}

The questionnaire also contains three open questions about which factors could enhance or limit the EP gain (questions 18-19), and which program aspects needed improving (question 20).

A group interview was then conducted in a conversational style to gain further information on training effectiveness because of the power imbalance between the trainees and the researcher as an insider lecturer. This would reduce anxiety, increase comfort and confidence in sharing ideas, and allow free interactions and mutual catalysts (Taber, 2013). Open-ended questions are employed to elicit free opinions. The following questions were posed in Vietnamese, and prompts were used to develop the talk: What would say about the effectiveness of EP courses? Do you feel that the EP training helped you improve your EP? To what extent did they prepare you for the C1 level? 


\subsection{Context and Participants}

The study was conducted at a representative public university in the Mekong Delta. As per admission procedure, candidates to the four-year 140-credit ELTEP submit the results of three tests: mathematics (or geography, or history), literature and English, and are recruited basing on the in-take year quota. When admitted, they follow a mandated training structure: $30 \%$ of the total credits are for general knowledge delivered in Vietnamese, and 70\% for the professional knowledge. The 2014-2018 program consisted of linguistics and culture courses $(9.3 \%)$, courses on general and subject-specific pedagogy, assessment, technology for teaching and practicum $(32.2 \%)$ and EP courses $(28.5 \%)$. The time for EP equals to 787 in-class contact hours; each contact hour requires students to take two self-study hours. All the EP courses were aligned with the CEFR can-do abilities, starting with B1 and targeting C1. The EP courses relied on the two textbook series, North-star and Pathways, which endorse the communicative approach; accompanied with an IELT book series for guided self-study. They were delivered by lecturers who held Master's degrees in TESOL, or Applied Linguistics, and had a teaching experience of three years minimum. English was the main medium of instruction (EMI) in most professional knowledge courses.

Forty-one teacher trainees from the 2014-2018 in-take responded to the questionnaire, accounting for $50 \%$ of the population. They included 24 females $(58.6 \%)$ and 17 males $(41.5 \%) ; 30$ candidates (73.2\%) came from the countryside, and eleven $(26.8 \%)$ from the city. Their entry English score was $\mathrm{M}=6.99, \mathrm{SD}=$ .965 (out of ten). Of the total, $68.3 \%$ reported proficiency proofs equivalent to C1 level ${ }^{3}$, and $14.6 \%$ B2; while the EP qualification of the remaining ten participants was unknown. Regarding their training motivation, albeit the program outcome is the English teaching career, only $65.9 \%$ desired to pursue this career; $9.8 \%$ wanted to find any job that uses English; $14.6 \%$ elected the major because of free tuition ${ }^{4}$ mainly, and $2.4 \%$ followed their family advice or imposition, and $7.3 \%$ thought it is a popular language. Five males and two females who had obtained $\mathrm{C} 1$ volunteered to participate in the interview.

\subsection{Data collection and analysis procedures}

The questionnaire was put on Google Form and emailed to all the trainees in the program, accompanied by an invitation message at the end of their coursework before they left for the school practicum to complete their training. The participants had two weeks to respond to the invitation. The interview was conducted two weeks after that. Curricular documents were only consulted to obtain information on the intended goals and contents.

The returned questionnaire responses were collated into an excel file and transferred to the SPSS software. Cronbach's alpha coefficients were then calculated to assess the questionnaire reliability. Descriptive statistics were employed to depict the trainees' self-evaluation. Then, inferential statistics such as independent-samples t-tests and correlation tests were used to explore the

\footnotetext{
${ }^{3}$ Standard setting in Vietnam (IELTS-7.0, national VSTEP-level 5; TOEFL ITP-550; TOEFL iBT-80; TOEIC-850, CAE-180)

4 Teacher education programs are funded by the government, while tuition applies to other programs.
} 
differences in their EP, and the relationship between the training factors and the $\mathrm{EP}$ results. Given the only one-shot interview, it was only used to extract the evidence that could clarify the questionnaire results.

\section{Results}

\subsection{EFL teacher trainees' self-assessed EP levels}

Table 2: EFL teacher trainees' self-rated entry and exit levels of EP across skills

\begin{tabular}{|l|l|l|l|l|l|l|l|l|l|l|}
\hline \multirow{2}{*}{ Lkills } & \multicolumn{2}{|c|}{ Listening } & \multicolumn{2}{c|}{ Reading } & \multicolumn{2}{c|}{$\begin{array}{c}\text { Spoken } \\
\text { interaction }\end{array}$} & \multicolumn{2}{c|}{$\begin{array}{c}\text { Spoken } \\
\text { production }\end{array}$} & \multicolumn{2}{c|}{ Writing } \\
\cline { 2 - 14 } & Entry & Exit & Entry & Exit & Entry & Exit & Entry & Exit & Entry & Exit \\
\hline Mean & 2.05 & 4.49 & 2.44 & 4.71 & 1.93 & 4.58 & 1.95 & 4.54 & 2.12 & 4.61 \\
SD & .805 & .675 & .923 & .559 & .848 & .590 & .805 & .596 & .954 & .586 \\
\hline 1-A1 \% & 26.9 & - & 14.6 & - & 34.1 & - & 31.7 & - & 34.1 & - \\
\hline 2-A2 \% & 43.9 & 2.4 & 39.1 & - & 43.9 & - & 43.9 & - & 24.4 & - \\
\hline 3-B1 \% & 26.8 & 2.4 & 36.6 & 2.4 & 17.1 & 4.9 & 22 & 4.9 & 36.6 & 4.9 \\
\hline 4-B2 \% & 2.4 & 39.1 & 7.3 & 26.8 & 4.9 & 31.7 & 2.4 & 36.6 & 4.9 & 29.2 \\
\hline 5-C1 \% & - & 56.1 & 2.4 & 68.4 & - & 63.4 & - & 58.5 & - & 65.9 \\
\hline 6-C2 \% & - & - & & 2.4 & - & - & - & - & - & - \\
\hline
\end{tabular}

Table 2 reveals that the trainees started with various levels across all English skills. Between $26.9 \%$ and $34 \%$ began with level A1, and $43.9 \%$ had A2 for listening and speaking. Over one-third of the respondents attained B1 in reading and writing, while $26.8 \%$ and around $20 \%$ rated themselves on B1 for listening and speaking respectively. Only less than 5\% (2.4\% to $4.9 \%)$ believed they possessed an overall $\mathrm{B} 2$, or a reading proficiency equivalent to $\mathrm{C} 1$. Overall, most respondents assessed their EP level between $\mathrm{A} 2$ and $\mathrm{B} 1 \mathrm{M}=1.93, \mathrm{SD}=.848$ for speaking; $\mathrm{M}=2.44, \mathrm{SD}$ $=.923$ for reading), and they were less self-confident in listening and speaking than reading and writing abilities. Their individual variance was quite large (SD $=.805$ for listening and spoken production, and $\mathrm{SD}=.954$ for writing)

In contrast, their self-assessment upon training completion showed a significant gain, with all the skills being estimated from level B2. The mean scores increased to over $4.0(4.49-4.71)$, and the standard deviations decreased (.559-.675). They continued to show most confidence in reading (2.4\% attained C2, 68.4\% C1, 26.8\% B2, and $2.4 \%$ B1). Roughly similar numbers of participants self-rated their writing ability equivalent to C1 (65.9\%), B2 (29.2\%), and B1 (4.9\%). On average, both spoken interaction and production were rated closely the same $(\mathrm{M}=4.58$, and $\mathrm{M}$ $=4.54$ respectively). Specifically, $63.4 \%$ of trainees assessed their spoken interaction at $\mathrm{C} 1$, and $31.7 \%$ at $\mathrm{B} 2$, while ratings for spoken interaction were $58.5 \%$ and $36.6 \%$ respectively. A small amount $(4.9 \%)$ remained at B1. Their listening proficiency was ranked the lowest with only $56.1 \%$ of participants reporting level $\mathrm{C} 1,39.1 \% \mathrm{~B} 2,2.4 \% \mathrm{~B} 1$, and $2.4 \% \mathrm{~A} 2$.

On average, $62.4 \%$ of teacher trainees rated their $\mathrm{EP}$ as $\mathrm{C} 1$-equivalent upon completion of training. This number is comparable to $68.1 \%$ reporting official certificates of the same level. $28.7 \%$ of participants graded themselves on level B2, and $3.65 \%$ estimated their EP at level B1, which is the recommended starting standard (MOET, 2014). 


\section{Exploring trainees' EP differences}

To explore further, the participants were reassigned into two groups according to the Entry English scores: the below-seven, and the seven plus. Then comparing the self-rated EP means, we found that the below-seven group rated their onset proficiency at significantly lower level than the other group $(t=-3.17, p<.05)$. In contrast, the ratings of exit EP were not significantly different between the groups $(\mathrm{M}=4.44, \mathrm{SD}=.505$, and $\mathrm{M}=4.71, \mathrm{SD}=.443$ respectively, $\mathrm{t}=1.5, \mathrm{p}>.05)$. Regarding regional difference, the candidates coming from rural areas had significantly lower entry English scores than those from urban schools $(\mathrm{M}=6.73$ compared to $\mathrm{M}=7.7, \mathrm{p}<.05)$, but overall they self-evaluated their EP gain approximately the same at the end.

A Pearson's correlation test was run between the entry English scores and the selfrated exit EP levels, producing a significant but low coefficient $(\mathrm{r}=.324, \mathrm{p}<.05)$. A similar calculation revealed a significantly stronger positive correlation between the self-perceived entry level and the exit level $(\mathrm{r}=.514, \mathrm{p}<.05)$. This means that the higher EP candidates start with, the more likely they could attain the advanced level.

\subsection{Trainees' self-evaluation of EP training effectiveness factors}

\section{What is their evaluation of the effectiveness elements of EP training?}

Table 3: Trainees' perceived effectiveness of EP courses by percentage

\begin{tabular}{|l|c|c|c|c|}
\hline Items & Disagree & Unsure & Agree & $\begin{array}{c}\text { Strongly } \\
\text { agree }\end{array}$ \\
\hline $\begin{array}{l}\text { The language skills courses state clear goals for } \\
\text { developing EP. }\end{array}$ & 2.4 & 7.3 & 75.6 & 14.6 \\
\hline $\begin{array}{l}\text { The language skills courses have a clear link and } \\
\text { progress from easy to difficult levels. }\end{array}$ & 0 & 7.3 & 70.7 & 22 \\
\hline $\begin{array}{l}\text { The language skills courses satisfied your needs. } \\
\text { The language skills courses prepared you well for } \\
\text { the EP equivalent to C1. }\end{array}$ & 7.3 & 17.1 & 70.7 & 4.9 \\
\hline $\begin{array}{l}\text { The teaching and learning activities in the skills } \\
\text { courses helped you improve your EP. }\end{array}$ & 2.4 & 24.4 & 51.2 & 22 \\
\hline $\begin{array}{l}\text { Teachers' assessment in the skills courses pushed } \\
\text { you to improve your EP. }\end{array}$ & 7.3 & 17.1 & 56.1 & 19.5 \\
\hline
\end{tabular}

Seen from Table 3, the trainees overall agree on the effectiveness of EP courses. The majority contended that the courses had clear goals, and were well connected and progressed (over $86 \%$ and $92 \%$ respectively). $75.6 \%$ felt the courses met their needs, while only $17.1 \%$ were uncertain and $7.3 \%$ disagreed with this. For attaining $\mathrm{C} 1$, nearly $66 \%$ of the trainees were content that the courses sufficiently prepared them, $26.8 \%$ were unsure, and $7.3 \%$ disagreed. A majority $(73.2 \%)$, however, admitted that EP activities helped them improve their English to a large extent; while nearly one-fourth expressed uncertainty about this preparation. $75.6 \%$ of them also reported that assessment activities affected their learning to improve their EP.

In the interview, the interviewees overall express positive attitudes to the EP courses in terms of goal statement, logical linkage and needs satisfaction. 
However, they believed the order of training writing genres seemed unclear. For them, starting with writing general texts such as messages, memos and letters, then continuing with writing basic academic paragraphs seemed unclear, as one trainee said, "I can't see the difference in the level between 'Reading and Writing General Texts' and 'Basic Academic Writing and Reading'."

The choice of materials also presents gaps in the level progression and relevance. Different lecturers selected different textbooks from two different series suggested in the syllabuses. A male trainee mentioned, "It depends on the lecturers; one lecturer chose Pathways for the basic and intermediate courses, then in the subsequent course, another selected North star, and then for Critical Writing and Reading, another lecturer switched back to Pathways." The trainees further commented that North star was boring, and contained several topics irrelevant to their life and interest. One of the females recalled, "Even some lecturers commented the book is boring to them."

For following the course syllabuses, they said most of lecturers used the suggested textbooks, but tweaked some activities and contents to a certain degree. However, the concerning issues are the teaching method that failed to motivate them, and the ineffective exploitation of the textbooks. One male trainee said, "I think the contents were interesting, but the lecturers' methods failed to make the material interesting." Another male trainee complained, "Once a native-speaker teacher taught us; he either strictly followed the book or completely ignored it; some contents he substituted were inconsistent with the syllabus and caused us confusion; consequently, many students skipped his classes because they felt demotivated."

Regarding the question about awareness of the EP standard, only $65.9 \%$ of the trainees reported they were well-aware. In the interview, a female candidate noted, "As far as I know, many of my classmates now still believe that they don't need to achieve $\mathrm{C} 1$ as one of the requirements, and they don't care about it."

To the open-ended question "what do you suggest to improve the program towards EP development?" most of the opinions concentrate on three crucial issues. First, further EP courses should be offered with a focus on oral skill development. Second, general knowledge courses should be reduced so that they could better invest effort and time into the development of EP. They said studying many general knowledge courses shared their time budget. This factor is also frequently repeated as the one affecting their EP development in another openended question. Third, there should be more practice, instead of theory-laden lectures in many EMI courses.

\section{What types of teaching and assessment activities were often used in EP courses?}

To understand the training effectiveness further, 29 learning activities, and 13 assessment activities were grouped into categories. Table 4 reveals that both teacher-centered activities $(\mathrm{M}=3.88, \mathrm{SD}=.448)$ and summative assessment $(\mathrm{M}=$ $3.95, \mathrm{SD}=.462)$ recurred more regularly than learner-oriented activities $(\mathrm{M}=3.58$, $\mathrm{SD}=.463)$ and formative assessment $(\mathrm{M}=3.55, \mathrm{SD}=.524)$. The trainees' use of selfregulated learning strategies were relatively high $(\mathrm{M}=3.87, \mathrm{SD}=.524)$. 
Table 4: Teaching and assessment activities in EP courses

\begin{tabular}{|l|c|c|c|c|}
\hline EP Course Activities & Min. & Max. & Mean & SD \\
\hline $\begin{array}{l}\text { Teacher-centered } \\
\text { activities }\end{array}$ & 3.0 & 4.71 & 3.88 & .448 \\
\hline $\begin{array}{l}\text { Learner-centered } \\
\text { activities }\end{array}$ & 2.61 & 4.56 & 3.58 & .463 \\
\hline Summative assessment & 2.67 & 4.67 & 3.95 & .462 \\
\hline Formative assessment & 2.43 & 4.71 & 3.55 & .469 \\
\hline
\end{tabular}

In detailed examination, for the teacher-centered activities, textbook-based practice was often guided by the teacher $(\mathrm{M}=4.29, \mathrm{SD}=.601)$, followed by teacher feedback $(\mathrm{M}=4.12, \mathrm{SD}=.714)$, lectures $(\mathrm{M}=4.0, \mathrm{SD}=.866)$, and teacher-controlled practice $(\mathrm{M}=3.66, \mathrm{SD}=.728)$. For the learner-centred category, group discussion occurred most frequently $(\mathrm{M}=4.19, \mathrm{SD}=.557)$, followed by output and interaction tasks $(\mathrm{M}=3.93, \mathrm{SD}=.608)$. Other less recurrent activities involved strategy instruction, promoting strategy use on tasks, extensive reading, presentations, projects, and task-based, self and peer assessment. Summative tests were employed more repeatedly $(\mathrm{M}=3.95, \mathrm{SD}=.462)$ than alternative formative assessment such as project, portfolio, journal and so on $(\mathrm{M}=3.55, \mathrm{SD}=.469)$.

Table 5: Trainees' use of self-regulated learning strategies

\begin{tabular}{|c|c|c|c|c|}
\hline Items & Min. & Max. & Mean & SD \\
\hline Find out about course goals & 3.0 & 5.0 & 3.68 & .6099 \\
\hline Set goals for studying the course & 3.0 & 5.0 & 3.93 & .7208 \\
\hline Choose suitable learning strategies & 3.0 & 5.0 & 4.00 & .6325 \\
\hline $\begin{array}{l}\text { Plan to study and use learning } \\
\text { strategies }\end{array}$ & 3.0 & 5.0 & 4.00 & .7746 \\
\hline $\begin{array}{l}\text { Monitor and notice success or } \\
\text { problems }\end{array}$ & 2.0 & 5.0 & 3.80 & .67 \\
\hline $\begin{array}{l}\text { Evaluate and change strategies if } \\
\text { necessary }\end{array}$ & 2.0 & 5.0 & 3.80 & .67 \\
\hline \multicolumn{3}{|l|}{ Total } & 3.87 & .524 \\
\hline
\end{tabular}

Regarding the level of self-regulated learning $(\mathrm{M}=3.87, \mathrm{SD}=.524)$, Table 5 shows that the trainees usually set goals for what they wanted to learn, selected appropriate strategies for learning, monitored, evaluated and regulated their strategies when necessary $(\mathrm{M}=3.8-4.0)$. In contrast, they less frequently found out about course goals beforehand $(\mathrm{M}=3.68, \mathrm{SD}=.609)$.

\section{Discussion}

The results above reveal that overall the trainees make a significant progress in EP. A large proportion (62.4\%) reported the achievement of the advanced level both in terms of self-rating and EP proofs, and many candidates appeared to make much improvement given their low starting point (A2). This number is closely consistent with previous research especially for the oral proficiency (approximately 60\%) (Glisan et al., 2013), and is much higher than what Faez et al. (2019) found. The percentage closely matches the large proportion of A2-B2 at the beginning. The rest of candidates who achieved B1 to B2 appears sensible, given their lower starting point (A1). Despite the significant training effect, it seems that adequate preparation for the advanced EP remains a debate. 
Specifically, good proportion still desired further EP support, whereas the qualified candidates would be challenged to maintain their level upon entering careers being distracted by multiple factors (T. Nguyen \& Mai, 2015). This finding, as with previous research (Glisan et al., 2013), means that teachers' LP gaps could originate in pre-service teacher education. Ongoing professional development that emphasizes EP is necessary to ensure the new graduates' levels will not drop. Alternatively, as noted by Moeller (2013), it is hard to jump the hurdle to the advanced LP, if current training programs are not restructured or improved to respond better to the reality, this target will be unachievable.

Several related factors could mediate the trainees' EP outcome and hence should be considered. First, as indicated by Peacock (2009), the effect might be due to the clear structuring and organization of EP courses. However, the fact that many candidates were unaware of the EP standard and entered training without clear career goals could possibly reduce their time and effort commitment (Bolitho, 2016; Chambless, 2012), and the likelihood to achieve their goals (Ball, 2010, as cited in Moeller, 2013). The choice of some materials and lecturers' methods which failed to interest the trainees could have further exacerbated their motivation. This might have in turn undermined the program effectiveness (Peacock, 2009; Sovann \& Chomdokmai, 2012; Sung, 2009). The trainees' desire for further language support, much like in previous research (Uzun, 2016; Vold, 2017), also reflects the specific needs for EP regarding regional difference among the candidates. Given their varied start levels, certain students might need more extensive EP training than others. This means that the program should respond better to the candidates' needs, especially the less proficient ones.

The balance between theory and practice and between knowledge components in the program is a crucial factor to consider. $28.5 \%$ of credits devoted to EP coursework is incomparable to $41.5 \%$ for pedagogical and linguistic knowledge courses delivered in both Vietnamese and English. This imbalance could have reduced the impact on EP growth (Bolitho, 2016; Chacón, 2005; Chambless, 2012). Obviously, the contact hours fall within the range 700-800 for $\mathrm{C} 1$ achievement (Cambridge University Press, 2013). Nevertheless, as indicated in this study, trainees may enter the program with various backgrounds (e.g., initial levels, motivation, school education and residency), and given that second language acquisition depends on sociocultural constraints (Lantolf, Thorne \& Poehner, 2015), the existing time allocation seems to suffice only to push trainees up to two levels. This means those starting with the right level (A2-B1 at least) will be more likely to achieve the goal.

Other essential factors may be the teaching and assessment activities. Although a mixture of activity types were implemented, there were more lectures and textbook-based activities than learner-oriented activities. Learner autonomy was less often promoted by offering choices of study topics, and process-oriented activities namely portfolios, or projects. Further exploration about the relationships of assessment activities and EP course activities with the trainees' use of self-regulated learning strategies revealed significant but low correlations $(\mathrm{r} .=.39, \mathrm{p}=.008$, and $\mathrm{r} .=.36, \mathrm{p}=.012$ respectively); however, a slightly higher correlation was observed between self-regulated learning strategies and the EP outcome $(\mathrm{r} .=.42, \mathrm{p}<.05)$. This suggests that the type of course and assessment 
activities may mediate the level of self-regulation which in turn impacts EP development (Fukuda, 2017).

Noticeably, the onset EP is a significant factor to predict LP gain (L. Nguyen, 2014). Despite the tuition-free policy for teacher education in the context which aims to recruit the best candidates, findings from this study show that a majority of candidates were below the onset required level (B1). This is due to the recruitment procedure which rigidly relied on the English test whose validity and reliability are doubted with respect to GLP assessment. This is evident in the low correlation between the test scores and the exit EP level, while a stronger correlation existed between the self-rated initial EP and the gained EP. This finding echoes a concern that has been raised in other contexts (Bolitho, 2016; Sandhu, 2016). As Bolitho (ibid.) noted, in many contexts "entry-level requirements are frequently relaxed..., which means that the profession does not always receive the best possible candidates" (p. 28).

\section{Implications}

Despite the limitations regarding the lack of process-oriented evaluation data, and a small sample size that limits generalizations, this study offers some implications for LP standardization in FLTE. Firstly, it is evident that the current program responds better to candidates with a proper starting level (A2-B1). Therefore, FLTE institutions should consider additional measures to recruit those candidates with the right levels. For the local program in this study, given the variant onset levels of the candidates as evident in their English test scores and EP self-rating, the collaboration of related recruitment units is necessary to further examine future candidates' speaking and listening skills to ensure the suitable candidates be recruited.

Additionally, current FLTEPs need to respond better to the demands of teacher trainees for LP development. Specifically, consideration should be taken into the balance between LP coursework and theoretical knowledge components. Further curricular changes are required to increase the LP proportion, and especially reducing coursework $(30 \%)$ perceived as unrelated to their professional training. Alternatively, additional opportunities for LP development can be designed into LP courses for enriching exposure to authentic materials and practice of English. For example, in-class instruction can be integrated with online learning resources and activities, using learning management systems.

Third, this study reveals that among the many mediating factors, teaching and assessment activities that push learner self-regulated learning and autonomy can enhance LP gain. Therefore, it is suggested that classroom instruction deploy more learner-centred activities and formative assessment to push the trainees' use of learning strategies. Self-assessment using the CEFR grid is advisable to raise students' awareness of the outcome goal and identify their gaps so that they can have timely LP supports (Pearson et al., 2006). It is stressed that the responsibility of all program constituents namely educators, trainees, and related departments and units will help achieve the goal (Moeller, 2013). 


\section{Conclusion}

Teacher capacity primarily relies on initial teacher education. Expectations seem high compared to the current reality, but measures taken to ensure the quality of pre-service FLTEPs will urge would-be teachers to meet the LP standard goal. Findings from this study on the EP training effectiveness at a large university in the Mekong Delta suggest that the feasibility in attaining the advanced EP goal remains an issue for further exploration across variable local contexts, especially disadvantaged areas. It is arguable that this level is achievable if teacher candidates have the right LP qualifications before training. Besides this, other potential factors to consider are learner-oriented course and assessment activities, self-regulated learning strategy use, and a balance between LP and other knowledge components. Despite the socio-cultural context where this study was conducted, we hope to contribute further understanding about features of ETEPs with respect to teachers' LP preparation. Future studies in other contexts which employ both quantitative and qualitative data to follow teachers' LP development may help to depict a fuller picture that informs teacher education towards the LP standardization policy.

\section{Acknowledgements}

We acknowledge special thanks to the participants of the study. We also thank the reviewers for their constructive comments.

\section{References}

ACTFL. (2012). ACTFL Proficiency Guidelines. ACTFL Language Connects. https://www.actfl.org/publications/guidelines-and-manuals/actfl-proficiencyguidelines-2012

Akcan, S. (2016). Novice non-native English teachers' reflections on their teacher education programs and their first years of teaching.Profile: Issues in Teachers' Professional Development, 18(1), 55-70.

Aldoobie, N. (2015). ADDIE Model. American International Journal of Contemporary Research, $5(6), 68-72$.

Baecher, L. (2012). Feedback from the field: What novice PreK-12 ESL teachers want to tell TESOL teacher educators. Tesol Quarterly, 46(3), 578-588. https://doi.org/10.1002/tesq.43

Bolitho, R. (2016). The ingedrients of quality in teacher education. In G. Pickering \& P. Gunashekar (Eds.), Ensuring Quality in English Language Teacher Education (pp. 2632). India: British Council.

Butler, Y. G. (2004). What level of English proficiency do elementary school teachers need to attain to teach EFL? Case studies from Korea, Taiwan, and Japan. Tesol Quarterly, 38(2), 245-278. https://doi.org/10.2307/3588380

Byram, M., \& Parmenter, L. (Eds.) (2013). The common european framework of reference: The globalisation of language education policy. Multilingual Matters.

Cambridge University Press. (2013). Introductory Guide to the Common European Framework of Reference (CEFR) for English Language Teachers. https://www.englishprofile.org/images/pdf/GuideToCEFR.pdf

Canale, M., \& Swain, M. (1980). Theoretical bases of communicative approaches to second language teaching and testing. Applied Linguistics, 1, 1-47. http://dx.doi.org/10.1093/applin/I.1.1 
Cárdenas, R., \& Chaves, O. (2013). English teaching in Cali: Teachers' proficiency level described. Lenguaje, 41(2), 325-352.

Carmel, R., \& Badash, M. (2018). Views on attrition and retention among beginning English as a foreign language (EFL) teachers in Israel and implications for teacher education. Teaching and Teacher Education, 70, 142-152. https://doi.org/10.1016/j.tate.2017.11.014

Chacón, C. T. (2005). Teachers' perceived efficacy among English as a foreign language teachers in middle schools in Venezuela. Teaching and Teacher Education, 21(3), 257272. https://doi.org/10.1016/j.tate.2005.01.001

Chambless, K. S. (2012). Teachers' oral proficiency in the target language: Research on its role in language teaching and learning. Foreign Language Annals, 45(1), 141-162. https://doi.org/10.1111/j.1944-9720.2012.01183.x

Chen, Z., \& Goh, C. (2011). Teaching oral English in higher education: challenges to EFL teachers. Teaching in Higher Education, 16(3), 333-345. https:// doi.org/10.1080/13562517.2010.546527

Choi, E., \& Lee, J. (2016). Investigating the relationship of target language proficiency and self-efficacy among nonnative EFL teachers. System, 58, 49-63. https:// doi.org/10.1016/j.system.2016.02.010

Copland, F., Garton, S., \& Burns, A. (2014). Challenges in teaching English to young learners: Global perspectives and local realities. Tesol Quarterly, 48(4), 738-762. https://doi.org/10.1002/tesq.148

Council of Europe. (2001). Common european framework of reference for languages: Learning, teaching, assessment. Cambridge University Press. https://rm.coe.int/1680459f97

Diamond, L., Sukyung, W. F., Gonzalez, J., Jacobs, E. A., \& Gany, F. (2014). Relationship between self-assessed and tested non-English language proficiency among $\begin{array}{llll}\text { primary care } & \text { providers. Medical } & \end{array}$ https://doi.org/10.1097/MLR.0000000000000102

Eslami, Z., \& Fatahi, A. (2008). Teachers' sense of self-efficacy, English proficiency, and instructional strategies: A study of nonnative EFL teachers in Iran. TESL-EJ, 11(4). http://tesl-ej.org/ej44/a1.html

Faez, F., \& Valeo, A. (2012). TESOL teacher education: Novice teachers' perceptions of their preparedness and efficacy in the classroom. Tesol Quarterly, 46(3), 450-471. https://doi.org/10.1002/tesq.37

Faez, F., Karas, M., \& Uchihara, T. (2019). Connecting language proficiency to teaching ability: A meta-analysis. Language Teaching Research. Advance online publication. https://doi.org/10.1177/1362168819868667

Freeman, D., Katz, A., Gomez, P. G., \& Burns, A. (2015). English-for-Teaching: Rethinking teacher proficiency in the classroom. ELT Journal, 69(2), 129-139. https://doi.org/10.1093/elt/ccu074

Fukuda, A. (2017). The Japanese EFL Learners' self-regulated language learning and proficiency. Journal of Pan-Pacific Association of Applied Linguistics, 22(1), 65-87. https://doi.org/10.25256/PAAL.22.1.4

Ghasemboland, F., \& Hashim, F. B. (2013). Teachers' self-efficacy beliefs and their English Language proficiency: A study of nonnative EFL teachers in selected language centers. Procedia - Social and Behavioral Sciences, 103, 890-899. https://doi.org/10.1016/j.sbspro.2013.10.411

Glisan, E. W., Swender, E., \& Surface, E. A. (2013). Oral proficiency standards and foreign language teacher candidates: Current findings and future research directions. Foreign Language Annals, 46(2), 264-289. https://doi.org/10.1111/flan.12030 
Gunashekar, P. (2016). Teacher education and quality assurance. In G. Pickering \& P. Gunashekar (Eds.), Ensuring quality in English language teacher education (pp. 1626). India: British Council.

Hadi, A. (2019). Exploring preparation of pre-service teachers' english proficiency and pedagogy: Stories from an EFL teacher education program. The Qualitative Report, 24(8), 1946-1966.

Kiely, R., \& Askham, J. (2012). Furnished imagination: The impact of preservice teacher training on early career work in TESOL. Tesol Quarterly, 46(3), 496-518. https://doi.org/10.1002/tesq.39

Kissau, S., \& Algozzine, B. (2017). Effective foreign language teaching: Broadening the concept of content knowledge. Foreign Language Annals, 50(1), 114-134. https://doi.org/10.1111/flan.12250

Lantolf, J. P., Thorne, S. L., \& Poehner, M. E. (2015). Sociocultural theory and second language development. In B. VanPatten \& J. Williams (Eds.), Theories in second language acquisition: An introduction ( $2^{\text {nd }}$ ed., pp. 207-227). Routledge.

Le, V. C., \& Renandya, W. (2017). Teachers' English proficiency and classroom language use: A conversation analysis study. RELC Journal, 48(1), 67-81. https://doi.org/10.1177\%2F0033688217690935

Ma, W., \& Winke, P. (2019). Self-assessment: How reliable is it in assessing oral proficiency over time?. Foreign Annguage Annals, 52(1), 66-86. https://doi.org/10.1111/flan.12379

Moeller, A. J. (2013). Advanced low language proficiency-An achievable goal? The Modern Language Journal 97 (2), 549-553. https://doi.org/10.1111/j.15404781.2013.12021.x

MOET. (2014). Guidelines for English Proficiency for School Teachers [Document 792/BGDĐTNGCBQLGD]. $\quad$ https://thuvienphapluat.vn/cong-van/Lao-dong-Tienluong/Cong-van-792-BGDDT-NGCBQLGD-nam-2014-Yeu-cau-co-ban-nangluc-giao-vien-tieng-Anh-pho-thong-221908-aspx

NESA. (2017). English language proficiency of teachers for provisional or conditional accreditation policy. NSW Gouvernment, Education Standards Authority.

Nguyen, T. V. (2015). Nguyên nhân, thực trạng và giải pháp nâng cao trình độ học vấn cho vùng đồng bằng sông Cửu Long [Causes, status-quo and measures for updgrading the educational level of Mekong Delta region]. http://css.hcmussh.edu.vn/?ArticleId=354f89b8-d50c-45c8-bc3c-a4e05c6bcef5

Nguyen, V. L. (2014). Factors influencing the English proficiency growth of English education students at Can Tho University. Journal of Science, 32, 67-74.

Nguyen, V. T., \& Mai, K. N. (2015). Responses to a language policy: EFL teachers' voices. The European Journal of Social and Behavioural Sciences, 13, 180-1841. http://dx.doi.org/10.15405/ejsbs.164

Peacock, M. (2009). The evaluation of foreign-language-teacher education programs. Language Teaching Research, 13(3), 259-278. https://doi.org/10.1177/1362168809104698

Pearson, L., Fonseca-Greber, B., \& Foell, K. (2006). Advanced proficiency for foreign language teacher candidates: What can we do to help them achieve this goal? Foreign Language Annals, 39(3), 507-519. https://doi.org/10.1111/j.19449720.2006.tb02902.x

Pham, T. H. N. (2017). General English proficiency or English for teaching? The preferences of in-service teachers. RELC Journal, 49(3), 339-352. https://doi.org/10.1177/0033688217691446

Prime Minister (2008). Approving the Scheme on Foreign Language Teaching and Learning in the National Education System in the 2008-2020 Period [Decision No. 1400/QD-TTg]. 
https://thuvienphapluat.vn/archive/Quyet-dinh/1400-QD-TTgvb83815t17.aspx

Richards, H., Conway, C., Roskvist, A., \& Harvey, S. (2013). Foreign language teachers' language proficiency and their language teaching practice. The Language Learning Journal, 41(2), 231-246. https:// doi.org/10.1080/09571736.2012.707676

Richards, J. C. (2010). Competence and peformance in language teaching. RELC Journal, 41(2), 101-122. https:// doi.org/10.1177\%2F0033688210372953

Richards, J. C. (2015). Key issues in language teaching. Cambridge University Press.

Richards, J. C. (2017).Teaching English through English: Proficiency, pedagogy and performance. RELC Journal, 48(1), 7-30. https:// doi.org/10.1177/0033688217690059

Sandhu, H. (2016). Curriculum review: Need and modalities for prerequisite language competence in teacher education. In G. Pickering \& P. Gunashekar (Eds.), Ensuring Quality in English Language Teacher Education (pp. 69-75). India: British Council.

Senom, F., Zakaria, A. R., \& Shah, S. S. A. (2013). Novice teachers'challenges and survival: Where do Malaysian ESL teachers stand? American Journal of Educational Research, 1(4), 119-125. https:// doi.org/10.12691/education-1-4-2

Sovann, K., \& Chomdokmai, M. (2012). An evaluation of Cambodian English language pre-service teacher training program at National Institute of Education in Cambodia. HRD Journal, 3(1), 9-20.

Stedick, D. (2013). Embracing proficiency and program standards and rising to the challenge: A response to Burke. Modern Language Journal, 97, 535-538. https://doi.org/10.1111/j.1540-4781.2013.12017.x

Stern, H. H. (1983). Fundamental concepts of language teaching. Oxford University Press.

Sung, D. (2009). Attractive quality attributes of English language teaching at two East Asian universities. The Journal of Asia TEFL, 6(4), 131-149.

Taber, K. S.(Ed.).(2013). Classroom-based research and evidence-based practice: An introduction ( $2^{\text {nd }}$ ed.). Sage.

TESOL. (2010). Standards for the recognition of initial TESOL programs in P-12 ESL teacher education. TESOL International Association. http://www.tesol.org/advance-the-field/standards/tesol-caep-standards-forp-12-teacher-education-programs

Tsang, A. (2017). EFL/ESL teachers' general language proficiency and learners' engagement. RELC journal, 48(1), https://doi.org/10.1177/0033688217690060

Tsui, S. M. B. (2003). Understanding expertise in teaching: Case studies of second language teachers. Cambridge University Press.

Uzun, L. (2016). Evaluation of the latest English language teacher training programme in Turkey: Teacher trainees' perspective. Cogent Education, 3, 1-16. https://doi.org/10.1080/2331186X.2016.1147115

Vold, E. T. (2017). Qualifying foreign language teachers: Is teacher training enough? International Journal of Educational Research, 82, 40-53. http://dx.doi.org/10.1016/j.ijer.2016.12.002

Wilson, K. M. (1999). Validity of a global self-rating of ESL speaking proficiency based on an FSI/ILR-referenced scale. ETS Research Report Series, 2. ETS. https://doi.org/10.1002/j.2333-8504.1999.tb01811.x

Yilmaz, C. (2011). Teachers' perceptions of self-efficacy, English proficiency, and instructional stategies. Social Behavior and Personality, 39(1), 91-100. 
Yusuf, F. N., \& Novita, O. E. (2020). EFL teachers' perceived language proficiency and teaching effectiveness. Indonesian Journal of Applied Linguistics, 9, 580-588. https://doi.org/10.17509/ijal.v9i3.23208

\section{Appendix 1}

\section{Evaluation questionnaire}

This questionnaire aims to give you the opportunity to evaluate the English teacher training program you have followed. The main purpose is to obtain information on how effective it is to help you improve your English skills. This information is useful for improving training in the future. Please answer the questions as objectively as possible. It will take about 20 minutes. Thank you for your cooperation.

\section{Part 1: Personal information}

Please leave your information.

Email address:

Gender (1=Male, 2=Female). Mark only one oval.

$\circ 1$

$\circ 2$

Where do you come from? (1=Countryside, $2=$ City; $3=$ Suburbs). Mark only one oval.

$$
\begin{array}{cl}
\circ & 1 \\
\circ & 2 \\
\circ & 3
\end{array}
$$

When did you begin studying English? (1=elementary school, 2=secondary school, 3=high school). Mark only one oval.

$$
\begin{array}{ll}
\circ & 1 \\
\circ & 2 \\
\circ & 3
\end{array}
$$

What was your English score at the entrance exam? (e.g., $5 ; 6 ; 6.5)$

What was your total score of 3 subjects at the entrance exam?

What certificate did you have before entering the training programme at CTU? (e.g., IELTS 6.0;

TOEIC 500; PET, KET, FCE...)

What certificate do you currently have? (e.g., IELTS 6.0; TOEIC 500; PET, KET,

FCE...)

What is the most important reason why you chose English language education as your major? How many credits have you completed up to now? 


\section{Part 2: Questions}

\section{Please answer the following questions.}

1. Please assess your level of listening skills at the start of the program and NOW. Read the description below carefully and choose the one that best describes your level.

Mark only one oval per row.
A1
A2
B1
B2
$\mathrm{C} 1$
$\mathrm{C} 2$

At the start of the

program

NOW

\begin{tabular}{|l|l|}
\hline I can recognise familiar words and very basic phrases concerning myself, my family and \\
immediate concrete surroundings when people speak slowly and clearly.
\end{tabular}

2. Please assess your level of reading skills at the start of the programme and NOW. Read the descriptions below carefully and choose the one that best describes your level.

\begin{tabular}{|l|l|}
\hline I can understand familiar names, words and very simple sentences, for example on notices and \\
posters or in catalogues.
\end{tabular}


Mark only one oval per row.
A1
A2
B1
B2
$\mathrm{C} 1$
$\mathrm{C} 2$

At the start of

the program

NOW

3. Please assess your level of interaction skills at the start of the programme and NOW. Read the description below carefully and choose the one that best describes your level.

\begin{tabular}{|l|l|}
\hline I can interact in a simple way provided the other person is prepared to repeat or rephrase things at a \\
slower rate of speech and help me formulate what I'm trying to say. I can ask and answer simple \\
questions in areas of immediate need or on very familiar topics.
\end{tabular}

Mark only one oval per row.
A1
A2
B1
B2
$\mathrm{C} 1$
$\mathrm{C} 2$

At the start of

the program

\section{NOW}

4. Please assess your level of spoken production at the start of the programme and NOW. Read the description below carefully and choose the one that best describes your level.

\begin{tabular}{|l|l|l|}
\hline I can use simple phrases and sentences to describe where I live and people I know. \\
living conditions, my educational background and my present or most recent job.
\end{tabular}


Mark only one oval per row.
A1
A2
B1
B2
C1
$\mathrm{C} 2$

At the start of the program

\section{NOW}

5. Please assess your writing skills at the start of the program and NOW. Read the descriptions below and choose the one that best describes your level.

\begin{tabular}{|c|c|}
\hline \multicolumn{2}{|l|}{ Writing } \\
\hline & $\begin{array}{l}\text { I can write a short, simple postcard, for example sending holiday greetings. I can fill in forms with } \\
\text { personal details, for example entering my name, nationality and address on a hotel registration form. }\end{array}$ \\
\hline & $\begin{array}{l}\text { I can write short, simple notes and messages relating to matters in areas of immediate needs. I can } \\
\text { write a very simple personal letter, for example thanking someone for something. }\end{array}$ \\
\hline & $\begin{array}{l}\text { I can write simple connected text on topics which are familiar or of personal interest. I can write } \\
\text { personal letters describing experiences and impressions. }\end{array}$ \\
\hline & $\begin{array}{l}\text { I can write clear, detailed text on a wide range of subjects related to my interests. I can write an essay } \\
\text { or report, passing on information or giving reasons in support of or against a particular point of view. I } \\
\text { can write letters highlighting the personal significance of events and experiences. }\end{array}$ \\
\hline & $\begin{array}{l}\text { I can express myself in clear, well-structured text, expressing points of view at some length. I can write } \\
\text { about complex subjects in a letter, an essay or a report, underlining what I consider to be the salient } \\
\text { issues. I can select style appropriate to the reader in mind. }\end{array}$ \\
\hline & $\begin{array}{l}\text { I can write clear, smoothly-flowing text in an appropriate style. I can write complex letters, reports or } \\
\text { articles which present a case with an effective logical structure which helps the recipient to notice and } \\
\text { remember significant points. I can write summaries and reviews of professional or literary works. }\end{array}$ \\
\hline
\end{tabular}

Mark only one oval per row.
A1
A2
B1
B2
C1
$\mathrm{C} 2$

At the start of the program

\section{NOW}

6. Did you know from the beginning that C1 level was one of the goals of the training program? Mark only one oval.

$$
\begin{array}{ll}
\circ & \text { Yes } \\
\circ & \text { No }
\end{array}
$$

7. The language skills courses state clear goals for developing English proficiency. Mark only one oval. $(2=$ disagree, $3=$ unsure, $4=$ agree $)$

$$
\begin{array}{lllll}
1 & 2 & 3 & 4 & 5
\end{array}
$$

Strongly disagree

Strongly agree 
8. The language skills courses satisfied your needs. (2=disagree, $3=$ unsure, $4=$ agree. Mark only one oval.

\section{$\begin{array}{lllll}1 & 2 & 3 & 4 & 5\end{array}$}

\section{Strongly disagree Strongly agree}

9. The language skills courses prepared you well for the English proficiency equivalent to C1. (2=disagree, $3=$ unsure, $4=$ agree). . Mark only one oval.

\section{5}

\section{Strongly disagree \\ Strongly agree}

10. The teaching and learning activities in the skills courses helped you improve your English proficiency. Mark only one oval.

$\begin{array}{lllll}1 & 2 & 3 & 4 & 5\end{array}$

\section{Strongly disagree Strongly agree}

11. Teachers' assessment in the skills courses pushed you to improve your English proficiency. (2=disagree, $3=$ unsure, $4=$ agree). Mark only one oval.

$\begin{array}{lllll}1 & 2 & 3 & 4 & 5\end{array}$

Strongly disagree Strongly agree

12. The language skills courses have a clear link and progress from easy to difficult levels. (2=disagree, $3=$ unsure, $4=$ agree $)$. Mark only one oval.

$\begin{array}{lllll}1 & 2 & 3 & 4 & 5\end{array}$

\section{Strongly disagree Strongly agree}

13. The following courses helped develop your English proficiency towards the level of C1. Mark only one oval per row.

strongly Disagree unsure agree $\begin{aligned} & \text { strongly } \\ & \text { agree }\end{aligned}$
disagree

1. Linguistics courses (e.g., grammar, pronunciation, phonology, syntax, discourse analysis...)

2. English Speaking Cultures

3. Teaching Literature

4. Teaching Methodology courses

5. Testing and Assessment

6. Technology in teaching English

7. Problem Solving Skills

8. Professional Communication Skills

9. Curriculum Design

10.Second Language Acquisition 
14. How often did the teaching in language skills courses engage you in the following activities? Mark only one oval per row.

Always $\begin{aligned} & \text { Most of } \\ & \text { the time }\end{aligned}$ Sometimes Seldom Never

1. Presenting a topic assigned by the teacher

2. Group discussion on a topic

3. Role play or drama

4. Demonstration

5. Project (e.g. make a video clip, a guidebook, a survey,...)

6. Portfolio

7. Practice exercises from the textbooks (listen, read, write,...)

8. Self-assessing the tasks you have done

9. Giving feedback on your classmates' tasks

10. Listening to teachers' talks

11. Activities that help you know how to learn English

12. Writing reflections on your learning process

13. Communicative language games

14. Online forum managed by the teachers

15. Further practice of language skills on the e-learning system managed by the teachers

16. Pairwork exchanges

17. Reading further (materials online, newspapers, or books)

18. Listening further to English on public media

19. Further speaking practice outside classes

20. Regular review of important knowledge

21. Watching a video clip/film 
22. Learning the supplementary materials introduced in the course syllabus

23. Interaction with a peer to complete a task

24. Teachers' feedback on your work/tasks

25. Using strategies to complete a task

26. Controlled practice (e.g., repetition, completing a given pattern, or similar practice)

27. Learning activities linked to your experience or life outside the classroom

28. Presenting a topic of your interest/choice

29.Vocabulary and grammar practice

15. How often did the teaching in the other courses taught in English engage you in the following activities? Mark only one oval per row.

Always $\begin{aligned} & \text { Most of } \\ & \text { the time }\end{aligned}$ Sometimes Seldom Never

1. Presenting a topic assigned by the teacher

2. Group discussion on a topic

3. Role play or drama

4. Demonstration

5. Project (e.g. make a video clip, a guidebook, a survey,...)

6. Portfolio

7. Completing practice exercises from the textbooks or materials individually

8. Self-assessing the tasks you have done

9. Giving feedback on your classmates' tasks

10.Listening to teachers' talks

11. Activities that help you know how to learn 
12. Writing reflections on your learning process

13. Online forum managed by the teachers

14. Further practice on the elearning system provided by the teachers

15. Pairwork exchanges

16. Reading further (materials online, newspapers, or books)

17. Listening further to related materials

18. Further speaking practice outside classes

19. Regular review of important knowledge

20. Watching a video clip/film

21. Learning the supplementary materials introduced in the course syllabus

22. Interaction with a peer to complete a task

23. Teachers' feedback on your work/tasks

24. Using strategies to complete a task

25. Controlled practice (e.g., repetition, completing a given pattern)

26. Learning activities linked to your experience or life outside the classroom

27. Presenting a topic of your choice

15. How often was each of the following assessment forms used in the courses? Mark only one oval per row.

Most
Always the Sometimes Seldom Never
time

1. Regular tests/quizzes (multiple choice or essay)

2. Final-term tests 
3. Group assignments in form of essays or reports

4. Group presentation

5. Group project

6. Portfolio

7. Writing a journal/diary

8. Self-assessment forms

9. Teacher regular feedback

10.Assessment from other classmates

11. Individual assignments in form of essays or reports

12. Mind map/concept map

13. Participating in in-class tasks/activities

16. Are you satisfied with the following aspects? Mark only one oval per row.

$\begin{array}{llll}\begin{array}{l}\text { Very } \\ \text { satisfied }\end{array} & \text { Satisfied } & \begin{array}{l}\text { Not } \\ \text { sure }\end{array} \quad \text { Dissatisfied } & \begin{array}{l}\text { Extremely } \\ \text { dissatisfied }\end{array}\end{array}$

1. Teachers' English proficiency

2. Teachers' methods of teaching

3. Assessment methods

4. Contents of English major courses

5. Course delivering plan

6. Amount of class time for language skills courses

7. Learning Materials

8. Learning facilities

9. Teachers' knowledge of the subject taught

10. Structuring courses in the program 
17. How often did you do the following over the years of learning? Mark only one oval per row.
Always $\begin{aligned} & \text { Most of the Sometimes Seldom Never } \\ & \text { time }\end{aligned}$

1. find out about course goals

2. set your own goals for studying

what you feel necessary

3. choose learning strategies that

help achieve the goals

4. make a plan to study and use

learning strategies

5. monitor the process to notice

success or problems

6. evaluate and change the

strategies if necessary

18. Which factors in the training program helped you develop English proficiency? Explain how they influenced your EP development?

19. Which factors in the training program limited your development of English proficiency?

Why?

20. Which aspects of the training program do you think need improving to help you achieve C1?

21. Please leave your contact number if you want to participate in an interview in the next stage. 